\title{
lodometric Quantitative Analysis Method of Ascorbic Acid in Tablets
}

\begin{abstract}
COSTINELA VALERICA GEORGESCU ${ }^{1}$, CRISTIAN CATALIN GAVAT ${ }^{2 *}$, DOINA CARINA VOINESCU ${ }^{1}$
${ }^{1}$ Dunarea de J os of Galati University, Faculty of Medicine and Pharmacy, Department of Pharmacology and Clinical Department, 47 Domneasca Str.,800008, Galati, Romania

${ }^{2}$ Grigore T. Popa University of Medicine and Pharmacy, Faculty of Medical Bioengineering, Department of Biomedical Sciences, 16 Universitatii Str., 700115, Iasi, Romania

Ascorbic acid is a water-soluble vitamin provided with strong antioxidant action, that fulfills an important immune protective role of the body against infections and prevents various cancers appearance. The main goal of this study was to exactly quantify pure ascorbic acid in tablets of two pharmaceuticals. Proposed objective consisted in improvement and application of a iodometric titration method in ascorbic acid quantitative analysis. Ascorbic acid content per tablet in both studied pharmaceuticals was $173.84 \mathrm{mg}$, very close to official stated amount of active substance $(180 \mathrm{mg})$. Allowed percentage deviation from declared content of pure ascorbic acid was only $3.42 \%$, below maximum value of $\pm 5 \%$ imposed by Romanian Pharmacopoeia 10-th Edition, according to European and International standards. Statistical analysis confirmed experimental obtained results and revealed low Standard Error value SE $=0.214476$, which has fallen within normal limits. Confidence Level value $(95.0 \%)=0.551328$ and Standard Deviation SD = 0.525357. were within normal range of values. Relative Standard Deviation (Coefficient of variation or homogeneity) $R S D=26.268 \%$ was found below maximum range of accepted values (30-35\%). $P$ value $=$ 7.44. $10^{6}$ was located within normal limits, $P<0.001$, so the experimental obtained results has shown highest statistical significance. Thus, studied titration method can be successfully used in quantitative analysis of ascorbic acid from different samples.
\end{abstract}

Keywords: ascorbic acid, antioxidant action, quantitative analysis, iodometric titration, statistic study

Ascorbic acid is a potent reducing and antioxidant agent that functions in fighting bacterial infections, in detoxifying reactions, and in the formation of collagen in fibrous tissue, teeth, bones, connective tissue, skin, and capillaries [1,2].

Vitamin $C$ is a water-soluble compound with powerful antioxidant action that fulfills a significant immune protective role of the body against infections and various diseases. It increases general immunity of the human body and prevents different cancers appearance. Ascorbate supplementation in cancer patients, either enhances the antitumor effects of chemotherapy or reduces its toxicity [1-4].

This vitamin possesses powerful antioxidant action by making a redox oxidation-reduction system in the cells, which contributes to the non-enzymatic transport of hydrogen to the tissues. Antioxidant action is represented by the neutralization and destruction of free peroxide radicals and nitrosamines in the body. Also prevents free peroxide radicals synthesis and promotes enzymatic activity. Vitamin C functions, as a proton carrier in oxidoreductase-catalyzed reactions in human body (catalase, peroxidase, cytochrome-oxidase, various dehydrogenases) are important aspects of all biochemical processes based on electron redox transfers. Ascorbic acid has antitoxic action by effective body protection against harmful effects of organochlorinated, organo-mercury compounds, lead, cadmium, arsenic compounds [3-5] .

Vitamin $C$ is also referred to as hexuronic acid. Structurally, itis L-gulonic acid or L-glucuronic acid gammalactone. It is absorbed by active transport or passive diffusion and enters to the cells through a specific transport system that requires a glucose transporter. Insulin causes vitamin $C$ entry into the cell. Patients with unbalanced hyperglycemia and diabetes have low levels of vitamin C in the cell, which causes increased oxidative stress with high risk of atherosclerosis This vitamin is brought to the body exclusively by food intake, especially by daily consumption of fresh fruits and vegetables [1-5].

Fruits with the highest concentration of ascorbic acid are represented by sea buckthorn $(2500 \mathrm{mg} \%$, calculated per $100 \mathrm{~g}$ of fresh fruit), rosehip (1000 $\mathrm{mg} \%)$, fresh green pepper (184 mg\%), black blueberry (181 mg \%), green leaves of parsley (133 $\mathrm{mg} \%)$, tomatoes dried in the sun (112 mg \%), broccoli (89.2 mg \%), kiwi fruits (75 mg \%), fresh cauliflower $(70 \mathrm{mg} \%)$, berries (strawberries, blackberries, raspberries) $63 \mathrm{mg} \%$, citrus fruits (lemons, oranges grapefruits) with $53 \mathrm{mg} \%$ content, green spinach (52 mg \%) [5-7].

Ascorbic acid is directly involved in corticosteroids production and certain neurotransmitters synthesis (substances that allow nervous influx transmission). It is known ascorbic acid active involvement in glucose metabolism, collagen synthesis (by converting proline to hydroxyproline, the core component of collagen), folic acid and some amino acids metabolism and in immunological reactions that facilitate iron absorption in digestive tract.

Vitamin C is directly involved in glycosaminoglycans biosynthesis (polysaccharides present at the cell surface and in the extracellular matrix), Hyaluronic acid, present in the connective, epithelial and nervous tissue, fulfills an important biological moisturizing role of the skin, in maintaining the suppleness, elasticity and tonicity of the epidermis $[1-3,5]$.

Presence of vitamin $\mathrm{C}$ in the body prevents fat deposition in the liver and ensures normal liver cell function. Ascorbic acid has antiallergic action and significantly decreases the incidence of clots in the blood vessels. It keeps glutathione in reduced form, actively protects vitamins $A, B, E$ against oxidation and converts (reduces) $\mathrm{Fe}^{3+}$ to $\mathrm{Fe}^{2+}$ ions. Also activates folic acid (vitamin B9) in the body. Vitamin C is directly involved in protein and carbohydrate metabolism, increases resistance to infections by leukocyte activation,

*email : ccgavat70@yahoo.com; Phone: 0743-782544 
interferon production and maintains mucosal integrity [ 16].

Ascorbic acid deficiencycauses a disease called scurvy (scurvy disease), that manifests itself through frequent gingival bleeding, severe changes in connective tissue. Some of the characteristic signs consists of atypical structures involving collagen and glycosaminoglycans formation, blurry spots on the skin, frequently on thighs and legs, soft gums and bleeding of virtually all mucous membranes. There are also known disturbances of the osteogenesis process, with the appearance of spongy forms [3-7].

Recommended intake of vitamin $C$ to the human body is $60 \mathrm{mg} / \mathrm{Kg}$ body weight/day in adults. This value is the safety limit that prevents scurvy symptoms occurrence. Minimum required ascorbic acid intake to prevent scurvy is about $10 \mathrm{mg} / \mathrm{Kg}$ body weight/day [4-7].

The main goal of this study was to exactly quantify pure ascorbic acid in tablets of two pharmaceuticals. Pursued objectives consisted in the improvement and application of a iodometric titration method for pure ascorbic acid quantitative analysis. Another objective was to compare obtained results for the tablets of two producing companies one with each other and then referring to the Romanian Pharmacopoeia Rules, 10-th Edition and European Pharmacopoeia, 9-th Edition, with regard to permissible percentage deviations from the stated official amount of active substance on pharmaceuticals tablets [8].

\section{Experimental part}

Required chemical reagents and equipment

-iodine I, solution, $0.1 \mathrm{~N}$;

-sodium thiosulphate $\mathrm{Na}_{2} \mathrm{~S}_{2} \mathrm{O}_{3^{\prime}} 0.1 \mathrm{~N}$;

$0.1 \mathrm{~N}$;

standard solution of potassium dichromate $\mathrm{K}_{2} \mathrm{Cr}_{2} \mathrm{O}_{7}$,

-freshly prepared starch solutions, $1 \%$ and $2 \%$;

-sulfuric acid $\mathrm{H}_{2} \mathrm{SO}_{4}, 40 \%$;

-ascorbic acid tablets coming from two pharmaceutical manufacturing companies Fiterman ${ }^{\circledR}$ and Labormed $₫$;

$-300 \mathrm{~mL}$ volumetric flasks;

-graduated glass pipettes $1 \mathrm{~mL}, 5 \mathrm{~mL}$ and $10 \mathrm{~mL}$;

-Pellet Precisa $50 \mathrm{~mL}$ automated burette.

A firststep in volumetric quantitative analysis of ascorbic acid consisted in $\mathrm{Na}_{2} \mathrm{~S}_{2} \mathrm{O}_{3^{\prime}} 0.1 \mathrm{~N}$ calibration on $\mathrm{K}_{2} \mathrm{Cr}_{2} \mathrm{O}_{7} 0.1$ $\mathrm{N}$ standard solution.

\section{Description of standardization methods}

Calibration procedure of iodine $I_{2}, 0.1 \mathrm{~N}$ solution was carried out in two different steps. The first stage consisted in :

Calibration of sodium thiosulphate $\mathrm{Na}_{2} \mathrm{~S}_{2} \mathrm{O}_{3^{\prime}}, 0.1 \mathrm{~N}$ on a standard solution of potassium dichromate $\mathrm{K}_{2} \mathrm{Cr}_{2} \mathrm{O}_{7} 0.1 \mathrm{~N}$.

Potassium dichromate $\mathrm{K}_{2} \mathrm{Cr}_{2} \mathrm{O}_{7}$ in strongly acidic medium $\left(\mathrm{H}_{2} \mathrm{SO}_{4}, 40 \%\right)$, stored in a dark place during 25 minutes in iodometric brown vials, has oxidized existing iodide $\mathrm{I}^{-}$anion from potassium iodide $\mathrm{KI}$ and has released an amount of iodine $\mathrm{I}_{2}$ equivalent to potassium dichromate quantity taken into experiment, in six titration beakers. Then, the iodine released was titrated with a $0.1 \mathrm{~N}$ sodium thiosulphate $\mathrm{Na}_{2} \mathrm{~S}_{2} \mathrm{O}_{3}$ solution from burette, until a yellowish-green coloration has appeared in titration beakers, in presence of $1 \mathrm{~mL}$ starch freshly prepared $1 \%$. Titration process took place until the color of the solution has changed to transparent blue - greenish in equivalence point. Volumes of $\mathrm{Na}_{2} \mathrm{~S}_{2} \mathrm{O}_{3}, 0,1 \mathrm{~N}(\mathrm{~V})$ consumed from burette to equivalence point were measured (table 1 ). Chemical reaction has taken place as follows:
$\mathrm{K}_{2} \mathrm{Cr}_{2} \mathrm{O}_{7}+6 \mathrm{KI}+7 \mathrm{H}_{2} \mathrm{SO}_{4}=\mathrm{Cr}_{2}\left(\mathrm{SO}_{4}\right)_{3}+3 \mathrm{I}_{2}+4 \mathrm{~K}_{2} \mathrm{SO}_{4}+7 \mathrm{H}_{2} \mathrm{O}$

$\mathrm{I}_{2}+2 \mathrm{Na}_{2} \mathrm{~S}_{2} \mathrm{O}_{3}=2 \mathrm{NaI}+\mathrm{Na}_{2} \mathrm{~S}_{4} \mathrm{O}_{6}$

Fig. 1 Sodium thiosulphate $0.1 \mathrm{~N}$ standardization- chemical reactions

Required volumes of $0.1 \mathrm{~N}$ potassium dichromate taken into beakers $\left(\mathrm{V}^{\prime}\right)$ and $0.1 \mathrm{~N}$ sodium thiosulphate consumed from burette to equivalence point $(V)$, were written in table 1. A series of important improvements have been made to initial titration method: increased corresponding amounts of 1.0, 1.4, 1.8, 2.2, 2.6, 3.0 g KI solid salt (a greater excess) were weighed and brought progressively (table 1) with corresponding increased distilled water volumes into six iodometric brown glasses., compared to the basic method in which only $1 \mathrm{~g} \mathrm{Kl}$ solid salt was weighed constantly.

Sulfuric acid concentration was increased from $25 \%$ in classical method, to $40 \%$, absolutely necessary to create a much stronger acidity. Gradually, increasing volumes of $\mathrm{H}_{2} \mathrm{SO}_{4}, 40 \%$ were added into each iodometric brown flask, over existing solutions (table 1). Storage time in a dark place was increased from $5 \mathrm{~min}$ in basic method, to 25 min nin curent proposed procedure, so the entire amount of existing iodide anions ( $(1)$ be oxidized to elemental iodine $\left(I_{2}\right)$. Three titrations were made for each studied volume (table 1) of potassium dichromate $\left(\mathrm{V}^{\prime}\right)$.

\section{Calculation method}

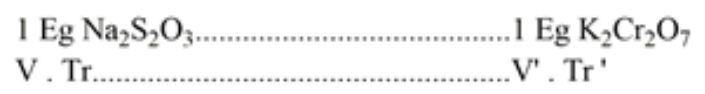

$$
\operatorname{Tr}=\left(\mathrm{Eg} \mathrm{Na}_{2} \mathrm{~S}_{2} \mathrm{O}_{3} \cdot \mathrm{V}^{\prime} \cdot \mathrm{Tr}^{\prime}\right) /\left(\mathrm{Eg} \mathrm{K}_{2} \mathrm{Cr}_{2} \mathrm{O}_{7}, \mathrm{~V}\right)
$$

where: $\mathrm{Tr}=$ real titer of $\mathrm{Na}_{3} \mathrm{~S}_{2} \mathrm{O}_{3}, 0.1 \mathrm{~N}$; $\mathrm{Tr}^{\prime}$ (real titer of $\left.\mathrm{K}_{2} \mathrm{Cr}_{2} \mathrm{O}_{7}, 0.1 \mathrm{~N}\right)=\mathrm{Tt}^{\prime}$ (theoretical titer of $\mathrm{K}_{2} \mathrm{Cr}_{2} \mathrm{O}_{7}, 0.1 \mathrm{~N}$ ) = $\left(\mathrm{Eg} \mathrm{K}_{2} \mathrm{Cr}_{2} \mathrm{O}_{7}\right.$. N) / $1000(\mathrm{~g} / \mathrm{mL}) ; \mathrm{Eg} \mathrm{Na} \mathrm{S}_{2}^{2} \mathrm{O}_{3}=$ gramequivalent of $\mathrm{Na}_{2} \mathrm{~S}_{2} \mathrm{O}_{3}=\mathrm{M} \mathrm{Na}_{2} \mathrm{~S}_{2} \mathrm{O}_{3} ; \mathrm{Eg} \mathrm{K}_{2} \mathrm{Cr}_{2} \mathrm{O}_{7}=\mathrm{gram}$ equivalent of $\mathrm{K}_{2}^{2} \mathrm{Cr}_{2}^{3} \mathrm{O}_{7}=\mathrm{M}^{2} \mathrm{~K}_{2}^{2} \mathrm{Cr}_{2} \mathrm{O}_{7} / 6_{1}, \mathrm{~V}^{2}=$ sodium thiosulphate $\left(\mathrm{Na}_{2} \mathrm{~S}_{2} \mathrm{O}_{3}\right) 0.1 \mathrm{~N}$ volumes conumed from burette to equivalence point. $V^{\prime}=$ potassium dichromate $\left(\mathrm{K}_{2} \mathrm{Cr}_{2} \mathrm{O}_{7}\right) 0.1 \mathrm{~N}$ volumes taken for analysis into six titration beakèrs (table 1) ; $\mathrm{M} \mathrm{Na} \mathrm{S}_{2} \mathrm{O}_{3}=$ molecular weight of sodium thiosulfate $=248.18 \mathrm{~g}_{;}, \mathrm{M} \mathrm{K}_{2} \mathrm{Cr}_{2} \mathrm{O}_{7}=$ molecular weight of potassium dichromate $=29^{2} .177^{7} \mathrm{~g}$. Theoretical titer of sodium thiosulfate $\mathrm{T}_{\mathrm{t}}\left(\mathrm{Na}_{2} \mathrm{~S}_{2} \mathrm{O}_{3}\right)=\left(\mathrm{Eg}_{\text {(sodium thiosulfate) }}\right.$ $\left.\mathrm{Na}_{2} \mathrm{~S}_{2} \mathrm{O}_{3} \cdot \mathrm{N}\right) / 1000 .(\mathrm{g} / \mathrm{mL})$.

According to ecuation (1), six real titers (Tr) of $\mathrm{Na}_{2} \mathrm{~S}_{2} \mathrm{O}_{3}$ $0.1 \mathrm{~N}$ were calculated and average real titer ( $\mathrm{Tr}$ sodium thiosulphate $\mathrm{Na}_{2} \mathrm{~S}_{2} \mathrm{O}_{3}, 0.1 \mathrm{~N}$ was obtained. the normality factor of $\mathrm{Na}_{3} \mathrm{~S}_{2} \mathrm{O}_{3}, 0.1 \mathrm{~N}$ was determined: $\mathrm{f}=\mathrm{Tr}$ averae $/ \mathrm{Tt} \mathrm{Na} \mathrm{S}_{2} \mathrm{O}_{3}(2)^{2}$, Tt $\mathrm{Ta}_{2} \mathrm{~S}_{2} \mathrm{O}_{3}$ has represented theoretical titer of $\mathrm{Na}_{2} \mathrm{~S}_{2} \mathrm{O}_{3}, 0.1 \mathrm{~N}$ solution, $\mathrm{Tt} \mathrm{Na} \mathrm{S}_{2} \mathrm{O}_{3}=$ (Eg $\mathrm{Na}_{2} \mathrm{~S}_{2} \mathrm{O}_{3}$. N) ${ }^{2} 1000(\mathrm{~g} / \mathrm{mL})$. For accurate measurements, $0.9 \leq \mathrm{f} \leq 1.1$.

The second step was consisted of iodine $\mathrm{I}_{2} 0.1 \mathrm{~N}$ calibration process and has been represented by:

Standardization of iodine $\mathrm{I}_{2} 0.1 \mathrm{~N}$ on a calibrated solution of sodium thiosulphate $\mathrm{Na}_{2} \mathrm{~S}_{2} \mathrm{O}_{3^{\prime}} 0.1 \mathrm{~N}$

Volumes of iodine $\mathrm{I}_{2} 0.1 \mathrm{~N}$ solution from six titration beakers were titrated with a standardized $0,1 \mathrm{~N} \mathrm{Na}_{2} \mathrm{~S}_{2} \mathrm{O}_{3}$ from burette, until the solutions color has changed from reddish-brown to light-pale yellow. Titration process continued, in the presence of $1 \mathrm{~mL}$ starch $1 \%$, until the color of the six solutions has changed from dark bluegray to complete colorless at equivalence point. Different 
volumes of $\mathrm{Na}_{2} \mathrm{~S}_{2} \mathrm{O}_{3^{\prime}} 0.1 \mathrm{~N}\left(\mathrm{~V}_{1}\right)$ from burette consumed to equivalence, were measured and described in table 2.

$$
\mathrm{I}_{2}+2 \mathrm{Na}_{2} \mathrm{~S}_{2} \mathrm{O}_{3}=\mathrm{Na}_{2} \mathrm{~S}_{4} \mathrm{O}_{6}+2 \mathrm{NaI}
$$

Fig. 2 lodine $0.1 \mathrm{~N}$ standardization- chemical reaction

Experimental volumes of $0.1 \mathrm{~N}$ iodine taken into beakers $\left(\mathrm{V}_{2}\right)$ and $0.1 \mathrm{~N}$ sodium thiosulphate consumed from burette to equivalence point $\left(V_{1}\right)$, have been mentioned in table 2 .Three titrations were made for each studied volume of iodine $\mathrm{I}_{2}, 0.1 \mathrm{~N}$.

\section{Calculation procedure}

$$
\begin{aligned}
& 1 \mathrm{Eg} \mathrm{Na}_{2} \mathrm{~S}_{2} \mathrm{O}_{3} \ldots \ldots \ldots \ldots \mathrm{Eg} \mathrm{I}_{2} \\
& \mathrm{~V}_{1}, \mathrm{Tr}_{\text {average } \ldots \ldots \ldots \ldots \ldots \ldots \ldots \ldots \ldots \ldots \ldots \ldots \ldots \ldots \ldots \ldots \ldots}, \mathrm{V}_{2}
\end{aligned}
$$

$$
\mathrm{Tr}_{2}=\left(\mathrm{Eg} \mathrm{I}_{2} \cdot \mathrm{V}_{1} \cdot \mathrm{Tr}_{\text {average }}\right) /\left(\mathrm{Eg} \mathrm{Na}_{2} \mathrm{~S}_{2} \mathrm{O}_{3} \cdot \mathrm{V}_{2}\right)
$$

where: $\operatorname{Tr}_{2}=$ real titer of iodine $\mathrm{I}_{2}, 0.1 \mathrm{~N} ; \mathrm{Tr}_{\text {ere }}=$ average real titer of sodium thiosulphate $\mathrm{Na}_{2} \mathrm{~S}_{2} \mathrm{O}_{3^{\prime}}$ a. 1 areage $\mathrm{Eg} \mathrm{Na}_{2} \mathrm{~S}_{2} \mathrm{O}_{3}$ $=$ gram-equivalent of $\mathrm{Na}_{2} \mathrm{~S}_{2} \mathrm{O}_{3} ; \mathrm{Eg} \mathrm{I}_{2}=$ gram-equivalent of $\mathrm{I}_{2}=\mathrm{MI}_{2} / 2 ; \mathrm{MI}_{2}=$ molecular weíght of $\mathrm{I}_{2}=253.81 \mathrm{~g} ; \mathrm{V}_{1}$ $\stackrel{2}{=}$ sodium thiosulphate $0,1 \mathrm{~N}\left(\mathrm{Na}_{3} \mathrm{~S}_{2} \mathrm{O}_{3}\right)$ volumes conumed from burette to equivalence point, $V_{2}=$ iodine $0.1 \mathrm{~N}\left(\mathrm{I}_{2}\right)$ volumes taken for analysis in six titration beakers (table 2). Using ecuation (3), six real titers $\left(\mathrm{Tr}_{2}\right)$ of $\mathrm{I}_{2} 0.1 \mathrm{~N}$ solution were calculated and an average real titer $\left({\operatorname{~} r_{2}}_{2}\right.$ average $)$ of iodine $\mathrm{I}_{2}, 0.1 \mathrm{~N}$ has been calculated. Thus, the normality factor of $\mathrm{I}^{\prime}, 0.1 \mathrm{~N}$ was calculated:. $\mathrm{f}^{\prime \prime}=\mathrm{Tr}_{2}, \pi \mathrm{t} \mathrm{I}_{2}(4)$. $\mathrm{Tt} \mathrm{I}$, has represented theoretical titer of $\mathrm{I}_{2}, \mathrm{verae}, 1 \mathrm{~N}$ solution, $\mathrm{Tt} \mathrm{I}_{2}=$ $\left(E g I_{2}\right.$. N) / $1000(\mathrm{~g} / \mathrm{mL})$. Normality factor $f$ " had to be between: $0.9 \leq f^{\prime \prime} \leq 1.1$.

\section{Study of proposed dosing method was described by:}

Volumetric quantitative analysis of pure ascorbic acid in two brands of pharmaceutical tablets

Pure ascorbic acid in samples volumes $\left(V_{4}\right)$ added into six titration beakers of each of two pharmaceuticals, was oxidized to dehydroascorbic acid bya standardized I $0.1 \mathrm{~N}$ solution from burette $\left(\mathrm{V}_{5}\right)$ in strongly acidic medium $\left(\mathrm{H}_{2} \mathrm{SO}_{4}\right.$, $40 \%$ ), while elemental lodine $\left(I_{2}\right)$ was reduced to iodide (I) anion. Titration process was carried out in presence of starch, $2 \%$ with color change from colorless to persistent dark blue-grayto equivalence point. Chemical reaction took place as follows (fig. 3).

Vitamin C volumes of two samples solutions taken into beakers $\left(\mathrm{V}_{4}\right)$ and iodine $\mathrm{I}_{2}, 0.1 \mathrm{~N}$ standardized solution volumes consumed from burette to equivalence point $\left(V_{5}\right)$, were written in table 3 . Three titrations have been done for each studied volume of ascorbic acid sample.

Samples preparation. Average tablet weight of each of two pharmaceutical products was $m_{c}=0.5977 \mathrm{~g}$. Active substance (pure ascorbic acid) content in pharmaceutical tablet was reported to be $180 \mathrm{mg}$, the same value in both pharmaceuticals.

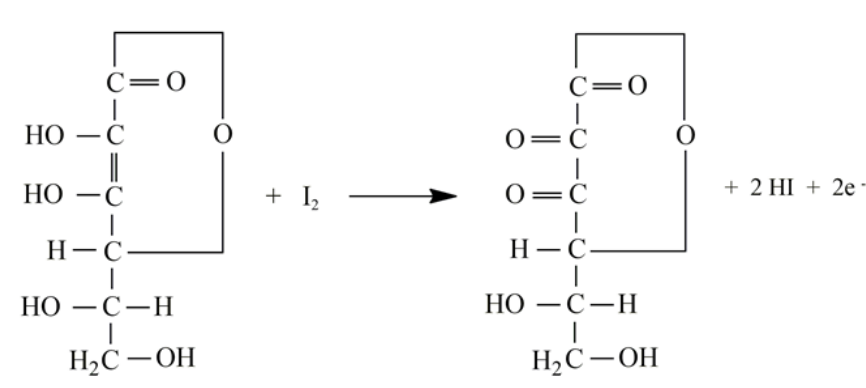

Ascorbic acid

Dehydroascorbic acid

Fig. 3 Titrimetric analysis of ascorbic acid - chemical reaction

Two samples made up of $a=0.5926 \mathrm{~g}$ vitamin $\mathrm{C}$ powder has been obtained from each of two pharmaceuticals, which were weighed and completely dissolved with $15 \mathrm{~mL}$ of 1,4-dioxane p.a. into two tightlyclosed volumetric flasks $V_{3}=500 \mathrm{~mL}$ each of them. Both contents were stirred well about 3-4 min, until complete dissolution of vitamin $\mathrm{C}$ pow der.

The volumetric flasks were filled out with distilled water to the mark. Different sample volumes of vitamin C were added in six titration beakers for each of two pharmaceuticals $\left(\mathrm{V}_{\mathrm{A}}\right)$, according to table 3 . In equivalence point (dark blue-gray color of solutions), titration processes were stopped and volumes of iodine $I_{2}, 0.1 \mathrm{~N}$ consumed from burette to equivalence point $\left(\mathrm{V}_{5}\right)$ were measured. Six titrations were performed for each pharmaceutical product powder sample and mean ascorbic acid $\left(Z_{1} \%\right)$ percent concentration was determined. Then, average concentration of ascorbic acid calculated on pharmaceutical tablet (T\%) and corresponding ascorbic acid amount measured in tablet of two pharmaceuticals $\left(X_{1} \mathrm{mg}\right)$ were calculated.

Some important improvements have been made to the original volumetric dosing method: both solid vitamin C powder samples were first completely dissolved in a small volume ( $15 \mathrm{~mL}$ each) of 1,4-dioxane p.a. as a polar solvent, compared to the original method. Then, the volumetric flasks were filled out to the mark with distilled water. During titration, 2\% freshly prepared starch and $\mathrm{H}_{2} \mathrm{SO}_{4} 40 \%$ solutions were used, two and four times more concentrated respectively, than those applied in the initial dosing procedure. Appropriate increasing volumes of starch $2 \%$ and concentrated $\mathrm{H}_{2} \mathrm{SO}_{4} 40 \%$ solutions were measured into six titration beakers, as shown in table 3 , compared to the original dosing method in which the volumes of added reagents were constant for all measurements ( $1 \mathrm{~mL}$ starch $1 \%$ and $5 \mathrm{~mL} \mathrm{H}_{2} \mathrm{SO}_{4} 2 \mathrm{~N}$ which has corresponded to $9.8 \%$. solution ).

\section{Calculation procedures}

A.Percentage concentrations ( $Z \%)$ of pure ascorbic acid from two pharmaceutical products samples and its average concentration $(Z, \%)$.

From chemical reaction (3), it was observed:

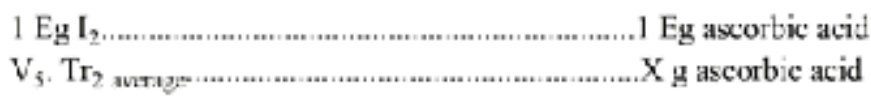

$\mathrm{X}=\left(\mathrm{Eg}\right.$ ascorbic acid $. \mathrm{V}_{5}, \mathrm{Tr}_{2}$ anrsuge $) / \mathrm{Eg} \mathrm{I}_{2}=$ amounts of pure ascorbic acid in $\mathrm{V}_{4} \mathrm{~mL}$ sample solutions from titration beakers, which reacted with $\mathrm{V}_{4} \mathrm{~mL}$ iodine $\mathrm{I}_{2}, 0,1 \mathrm{~N}$ from burette. 
$\mathrm{Xg}$ ascorbic ecid. $\mathrm{V}_{4} \mathrm{~mL}$ sample solutions

$\mathrm{Y} g$ ascorbic acid. $\mathrm{V}_{3} \mathrm{~mL}$ solution (volumetric flasks)

$\mathrm{Y}=\left(\mathrm{V}_{3} \cdot \mathrm{X}\right) / \mathrm{V}_{4}=$ amourts of purc ascorbic ecid in $\mathrm{V}_{3}=500 \mathrm{~mL}$ solution from volumetric flasks, which reacted with $\mathrm{V}_{5} \mathrm{~mL}$ iodine $\mathrm{I}_{2}, 0,1 \mathrm{~N}$ from burette.

(6)

\author{
a g....................................... Y g axcorbic acid \\ $100 \mathrm{~g}$ \\ $Z \%$ ascorbic acid \\ $Z=(100 . Y) i a(\%)$ in six titration measurements for each of two pharmaceuticals, then \\ average ascorbic acid $\left(Z_{1} \%\right)$ concentration in a g of powder samples was determined..
}

(')

\author{
B. Averane pure ascorbic acia' concantration (T\%) calculatod on zabiot of \\ pharwaceutzcal products.

(8)

C. Ascorbic acid pure content, measured in tablet of two pharmaceuticals ( $X_{1} \mathrm{mg}$ ), depending on average pure ascorbic acid concentration (T\%) and declared official content of active substance $(180 \mathrm{mg})$.

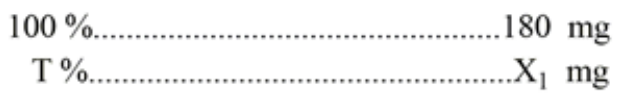

$\mathrm{X}_{1}=(\mathrm{T} .180) / 100=(\mathrm{mg})$ ascorbic acid pure contents calculated in tablet of two pharmaceuticals

(9)

Romanian Pharmacopoeia, 10-th Edition according to European and International in force rules, has confirmed the following percentage deviations from the declared active substance content [8].

$\begin{array}{lc}\text { Declared content: } & \text { Maximum allowed deviation } \\ \text { up to } 10 \mathrm{mg} & \pm 10 \% \\ 10 \mathrm{mg} \text { to } 100 \mathrm{mg} & \pm 7.5 \% \\ 100 \mathrm{mg} \text { and over } 100 \mathrm{mg} & \pm 5 \% .\end{array}$

\section{Statistic analysis}

A series of statistic parameters have been determined, using Microsoft Office Excel 2016 software: Standard Deviation (SD), Standard Error (SE), Sample Variance (SV), Relative Standard Deviation (Coefficient of variation or homogeneity) RSD \%, Confidence Level value (for 95\% degree of freedom ) and $P$ parameter value [9-13].

Standard Deviation (SD). This parameter was a measure of how widely individual values (measured $\mathrm{V}_{5}$ volumes of iodine $I_{2}$ from burette) are dispersed from the average value (the mean), how closely the data are clustered about the mean. Standard Deviation was a measure of the width of the distribution.

Standard Error(SE), has represented a measure of errors amount in y values prediction (measured $\mathrm{V}_{5}$ iodine $\mathrm{I}_{2} 0.1 \mathrm{~N}$ from burette) for an individual $x\left(\mathrm{~V}_{\mathrm{mL}} \mathrm{m}\right.$ acid ascorbic samples taken into titration beakers) [9-11].

Sample Variance (SV). expressed the relative distance between each data value and the mean and it has measured how the data (measured volumes $\mathrm{V}_{5}$ of iodine $\mathrm{I}_{2}, 0.1 \mathrm{~N}$ ) distributes itself about the mean (expected value). It has represented the square of the standard deviation [13-15].

Relative Standard Deviation (Coefficient of variation or homogeneity) RSD \%. Relative standard deviation (standard deviation divided by the mean), consisted in the deviation measurement about how different numbers in a particular data set (measured volumes $V_{5}$ of iodine $I_{2}, 0.1$ $N)$, have been scattered around the mean. This formula showed the spread of data in percentage.. It is also known as measure of variability of a series of numbers (Iodine $\mathrm{I}_{2}, 0.1 \mathrm{~N}$ consumed volumes from burette) , independently of the unit of measurement used for these numbers. Formula was given as: RSD \% $=\left(S D / X_{\text {mean }}\right) .100(10)$, 
whereas $\mathrm{SD}=$ standard deviation and $\mathrm{X}_{\text {man }}=$ average of the measured values. In this case, maximum range of allowed values was between $30-35 \%$ [9-15].

Confidence Level (95\% degree of freedom) has been described by the expression stating that the true mean was likely to lie within a certain distance from the measured mean of values.

All statistical parameters described above were calculated using Data $\rightarrow$ Data Analysis $\rightarrow$ Descriptive Statistics menu in Microsoft Office Excel 2016.

$P$ value, probability value or asymptotic significance used in context of null hypothesis, has been performed in order to exactly quantify, to assess statistical significance of measured values. This parameter highly expressed the veracity of obtained results. If $P<0.001$, than the results were highest statistically significant (less than one in a thousand chance of being wrong). For values ranged between $0.001<P<0.05$, the obtained results has presented a high statistically significance. If $0.05<P<$ 0.1 , than the result values had a much lower statistical significance. For $P$ values ranged within $P>0.1$, the resulting values presented lowest statistical significance [16-19]. P value was established using Data $\rightarrow$ Data Analysis $\rightarrow$ Anova Single Factor test.

\section{Results and discussions}

Standardization of sodium thiosulphate $\mathrm{Na}_{2} \mathrm{~S}_{2} \mathrm{O}_{3} 0.1 \mathrm{~N}$ by titration on a potassium dichromate $\mathrm{K}_{2} \mathrm{Cr}_{2} \mathrm{O}_{7}^{2} \mathrm{O} .1 \mathrm{~N}$ pure standard solution

In close correlation with equations (1) and (2), individual real titers, average titer value and normality factor of $\mathrm{Na}_{2} \mathrm{~S}_{2} \mathrm{O}_{3} 0.1 \mathrm{~N}$ solution were calculated. The obtained results were described in table 1 .

$\mathrm{Eg}$ (potassium dichromate) $\mathrm{K}_{2} \mathrm{Cr}_{2} \mathrm{O}_{7}=49,030 \mathrm{~g} \mathrm{~K}_{2} \mathrm{Cr}_{2} \mathrm{O}_{7}$. Potassium dichromate $\mathrm{K}_{2}, \mathrm{r}, \mathrm{O}, \mathrm{N}$, $\mathrm{N}$ standard solution titer was: $\mathrm{T}^{\prime}$ $=T_{t}{ }^{\prime}=0,0049030 \mathrm{~g} / \mathrm{mL}$, whereas $\mathrm{N}=$ normal concentration of the solution $=0.1$. Eg (sodium thiosulfate) $\mathrm{Na}_{2} \mathrm{~S}_{2} \mathrm{O}_{3}$ $=248.18 \mathrm{~g}$. Theoretical titer of sodium thiosulfate $T_{t}$ $\left(\mathrm{Na}_{2} \mathrm{~S}_{2} \mathrm{O}_{3}\right)=0.024818 \mathrm{~g} / \mathrm{mL}$
Normality factor (table 1 ) of $\mathrm{Na}_{2} \mathrm{~S}_{2} \mathrm{O}_{3} 0,1 \mathrm{~N}$ solution $\mathrm{f}=$ 1.0130 was located within the normal range of values $(0.9$ $\leq \mathrm{f} \leq 1.1)$.

Calibrating iodine I $0.1 \mathrm{~N}$ solution by titration on standardized sodium thiosulphate $\mathrm{Na}_{2} \mathrm{~S}_{2} \mathrm{O}_{3}, 0.1 \mathrm{~N}$

According to relations (3) and (4), six real titers, average titer value and normality factor of iodine $\mathrm{I}_{2}, 0.1 \mathrm{~N}$ solution were investigated. The obtained results were written in table 2.

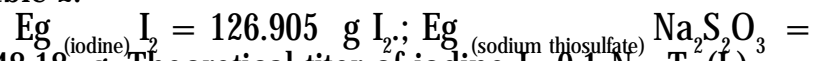
$248,18^{\text {iodine) }} \mathrm{g}$. Theoretical titer of iodine $\mathrm{I}_{2}$, $0,1 \mathrm{~N} \mathrm{~N}^{2} \mathrm{~T}_{t}^{2}\left(\mathrm{r}_{2}\right)^{3}=$ $0.0126905 \mathrm{~g} / \mathrm{mL}$. In correlation with table 2 , the normality factor of $I_{2} 0.1 \mathrm{~N}$ solution $f^{\prime \prime}=0.9694$ was within the normal range of values $(0.9 \leq f \leq 1.1)$.

\section{Volumetric quantitative analysis of pure ascorbic acid in two pharmaceuticals}

Ascorbic acid that came from Fiterman ${ }^{\circledR}$ and Labormed $\AA$ tablets, was titrated with exactly the same volumes of iodine $\mathrm{I}_{2}, 0.1 \mathrm{~N}$ solution from burette. Thus, the calculations values presented in table 3 were identical for vitamin $\mathrm{C}$ tablets which has belonged to both producing companies.

According to equations (5)-(9), percentage concentrations ( $Z \%)$ of pure ascorbic acid from powder samples $(a=0.5926 \mathrm{~g})$ of two pharmaceuticals and its related average value $(Z \%)$ were calculated, as well as ascorbic acid pure content $(X, \mathrm{mg})$ assigned to tablets of two pharmaceutical products. The obtained results were highlighted in table 3 .

Mean percent concentration of pure ascorbic acid in weighted sample $(a=0.5926 \mathrm{~g})$ was $95.76 \%$ and average percent concentration of ascorbic acid in vitamin $\mathrm{C}$ tablet $(\mathrm{m}=0.5977 \mathrm{~g}$.) has been assigned to $96.58 \%$ in both pharmaceuticals, with a maximum percent allowed deviation of $3.42 \%$, to the declared active substance content (180 mg).

\begin{tabular}{|c|c|c|c|c|c|c|c|c|}
\hline $\begin{array}{l}\text { Nr. } \\
\text { det. }\end{array}$ & $V^{\prime}(\mathrm{mL})$ & $\begin{array}{c}V \\
(\mathrm{~mL})\end{array}$ & $\mathrm{KI}(\mathrm{g})$ & $\begin{array}{l}V(\mathrm{~mL} \\
\left.\mathrm{H}_{2} \mathrm{O}\right)\end{array}$ & $\begin{array}{l}V_{\text {sulfuric acid }} \\
(\mathrm{mL})\end{array}$ & $\begin{array}{c}\mathrm{T}_{\mathrm{I}} \\
(\mathrm{g} / \mathrm{mL})\end{array}$ & $\begin{array}{l}T_{\text {r averago }} \\
(\mathrm{g} / \mathrm{mL})\end{array}$ & $f$ \\
\hline 1. & 10.0 & 9.8 & 1.0 & 20 & 6 & 0.025324 & \multirow{6}{*}{0.02514} & \multirow{6}{*}{1.0130} \\
\hline 2. & 12.0 & 11.9 & 1.4 & 30 & 7 & 0.025025 & & \\
\hline 3. & 14.0 & 14.0 & 1.8 & 40 & 8 & 0.024818 & & \\
\hline 4. & 16.0 & 15.9 & 2.2 & 50 & 9 & 0.024974 & & \\
\hline 5. & 18.0 & 17.6 & 2.6 & 60 & 10 & 0.025382 & & \\
\hline 6. & 20.0 & 19.6 & 3.0 & 70 & 11 & 0.025324 & & \\
\hline
\end{tabular}

Table 1

STANDARDIZATION OF SODIUM THIOSULPHATE $\mathrm{Na}_{2} \mathrm{~S}_{2} \mathrm{O}_{3} 0.1 \mathrm{~N}$

\begin{tabular}{|c|c|c|c|c|c|}
\hline $\begin{array}{l}\text { Nr. } \\
\text { det. }\end{array}$ & $\begin{array}{c}V_{2} \\
(\mathrm{~mL})\end{array}$ & $\begin{array}{c}V_{1} \\
(\mathrm{~mL})\end{array}$ & $\operatorname{Tr}_{2}(\mathrm{~g} / \mathrm{mL})$ & $\operatorname{Tr}_{1}$ merage $(\mathrm{g} / \mathrm{mL})$ & $\mathrm{f}^{\prime \prime}$ \\
\hline 1. & 10.0 & 9.5 & 0.012222 & \multirow{6}{*}{0.01230} & \multirow{6}{*}{0.9694} \\
\hline 2. & 12.0 & 11.2 & 0.012007 & & \\
\hline 3. & 14.0 & 13.6 & 0.012497 & & \\
\hline 4. & 16.0 & 15.3 & 0.012302 & & \\
\hline 5. & 18.0 & 17.3 & 0.012365 & & \\
\hline 6. & 20.0 & 19.3 & 0.012415 & & \\
\hline
\end{tabular}

Table 3

VOLUMETRIC ANALYSIS OF PURE ASCORBIC ACID IN BOTH BRANDS OF VITAMIN C TABLETS

\begin{tabular}{|c|c|c|c|c|c|c|c|c|c|c|}
\hline $\begin{array}{c}\text { Nr. } \\
\text { det. }\end{array}$ & $\begin{array}{c}\mathrm{V}_{4} \\
(\mathrm{~mL}) \\
\text { Ascarbic } \\
\text { scid }\end{array}$ & $\begin{array}{c}\mathrm{V}_{5} \\
(\mathrm{~mL}) \\
\text { Iodim }\end{array}$ & $\begin{array}{c}\mathrm{V}(\mathrm{mL}) \\
\text { sulfuric acid }\end{array}$ & $\begin{array}{c}\text { Starch, } \\
\% \\
(\mathrm{~mL})\end{array}$ & $\mathrm{X}(\mathrm{g})$ & $\mathrm{Y}(\mathrm{g})$ & $\mathrm{Z} \%$ & $\mathrm{Z}_{1} \%$ & $\mathrm{~T} \%$ & $\mathrm{X}_{1}(\mathrm{mg})$ \\
\hline 1 & 10 & 1.3 & 6 & 1.0 & 0.011097 & 0.5548 & 93.63 & & & \\
\hline 2 & 12 & 1.6 & 7 & 1.2 & 0.013658 & 0.5690 & 96.03 & \multirow{2}{*}{95.76} & 96.58 & \multirow{2}{*}{173.84} \\
\hline 3 & 14 & 1.8 & 8 & 1.4 & 0.015365 & 0.5487 & 92.60 \\
\hline 4 & 16 & 2.2 & 9 & 1.6 & 0.018780 & 0.5868 & 99.04 \\
\hline 5 & 18 & 2.4 & 10 & 1.8 & 0.020487 & 0.5690 & 96.03 \\
\hline 6 & 20 & 2.7 & 11 & 2.0 & 0.023048 & 0.5762 & 97.23 & & & \\
\hline
\end{tabular}


Table 4

OBTAINED VALUES OF SOME STATISTICAL PARAMETERS

\begin{tabular}{|c|c|c|c|c|c|}
\hline $\begin{array}{c}\text { Standard } \\
\text { Deviation (SD) }\end{array}$ & $\begin{array}{c}\text { Standard Error } \\
(\mathrm{SE})\end{array}$ & $\begin{array}{c}\text { Sample } \\
\text { Variance } \\
(\mathrm{SV})\end{array}$ & $\begin{array}{c}\text { Relative Standard Deviation } \\
\text { (RSD \%) }\end{array}$ & $\begin{array}{c}\text { Confidence Level (95\% } \\
\text { degree of freedom) }\end{array}$ & P value \\
\hline 0.525357 & 0.214476 & 0.276 & 26.268 & 0.551328 & $7.44 .10^{-6}$ \\
\hline
\end{tabular}

\section{Statistic study}

Following statistical analysis, the obtained results were presented in table 4 . All studied parameters ranged within normal limits.

Average of studied values, which were represented by volumes $\mathrm{V}_{5}$ of iodine $\mathrm{I}_{2}, 0.1 \mathrm{~N}$ consumed (table 3 ) from burette to equivalence point, was found to be 2 .

Standard Deviation SD $=0.525357$ and Sample Variance SV $=0.276$ (table 4 ), as direct measures of dispersion, were very low which meant that the experimental individual obtained values were tightly close one to each other and by the mean (expected value).

\section{Conclusions}

Following the iodometric dosing method of ascorbic acid in two pharmaceuticals, it was found, in both cases, that the average percent concentration of ascorbic acid in tablets was $96.58 \%$, the same in both pharmaceutical products. The amount of pure ascorbic acid in tablets was $173.84 \mathrm{mg}$, an identical value for both branded pharmaceutical products, which was very close to the stated amount of active substance by the producing companies (180 mg). Maximum percent deviation from declared active substance content in both pharmaceuticals has been only $3.42 \%$, which was located below maximum allowed value of $\pm 5 \%$ imposed by Romanian Pharmacopoeia X-th Edition, according to European and International Standards.

Performed statistical analysis has confirmed the experimental obtained results. Relative standard deviation $\mathrm{RSD}=26.268 \%$ was within the normal range of values, below maximum range of accepted values (30-35\%).. Standard error SE $=0.214476$, was found to be within the normal limits, for a confidence level of 0.551328 . Standard Deviation SD $=0.525357$. and Sample Variance SV = 0.276 were also in normal range of values.

Statistical $P$ parameter $P=7.44 .10^{-6}$ has reported a very small value. It has been observed that $P<0.001$, so all the experimental obtained results has shown highest statistical significance.

The iodometric dosing method can be successfully applied in quantitative analysis of ascorbic acid from different samples.
Acknowledgments. This paper is simply a scientific research study that does not aim to confirm or deny the official results obtained by pharmaceutical manufacturing companies, nor to cause any image damage or to trigger conflicts of interest.

\section{References}

1.HOWERDE, E., S., Annual Review of Nutrition, 14, 1994, p. 371-391. 2.ANDREAS, R., Current Medicinal Chemistry, 16, nr.2, 2009, p. 184188.

3.MARC, Y., L. and GUY, D., Genetica, 139, nr. 2, 2010, p. 199-207. 4. CARMEL, J., BRIAN, H., TERRY, N., RISA, S. and MARK, C., The Oncologist, 20, nr. 2, 2015, p. 210-223.

5.DEBRA, L., S., JOHN, F., K., ELISABETH, S., B., STHEPHEN, J., JAY, D., C., JOSEPH, A., V., Hypertension, 35, nr. 4, 2018, p. 936-941.

6. QI, C., KISHORE, P., PING, C., RUOCHEN, D., Canadian Journal of Physiology and Pharmacology, 93, nr.12, 2015. p. 1055-1063.

7.CUCIUREANU, R., Igiena Alimentului, 2, Edit, Performantica, Iasi, 2012, p. 109-132.

8.*** Farmacopeea Romana, 10, Agentia Nationala a Medicamentului (National Drug Agency), Edit. Medicala, Bucuresti, 1993, p. 977-1293. 9.DORNEANU, V., STAN, M., Chimie Analitica -Lucrari Practice, Edit. U.M.F. Grigore.T.Popa. Iasi, 2000, p. 311-317.

10.DORNEANU, V., STAN, M., MUSTEATA, M., F., Chimie Analitica, Edit. U.M.F. Grigore.T.Popa, lasi, 2003, p. 326-331.

11.DORNEANU, V., STAN, M., Metode Chimice si Instrumentale de Analiza, 2, Edit. U.M.F. Grigore.T.Popa, Iasi, 2007, p. 236-332

12.TROCHIM, W., M., K., Descriptive statistics. Research Methods Knowledge Base, 2006, http://www.socialresearchmethods.net/kb/ statdesc.php, accessed: August 09, 2018.

13.TODD, N., G., Descriptive Statistics. In: Topics in Biostatistics, Methods in Molecular Biology series, 12, 404, Humana Press: Springer, W. T. Ambrosius editor, New York, 2007, p. 33-52.

14.GEORGE, F., R., FREYJA, L., BRUCE, D., M., Clinical and Diagnostic Laboratory Immunology, 9, nr.6, 2002, p. 1235-1239..

15.SUBRAHMANYA, K., N., . and ARUNA, K., R., Communications in Statistics - Simulation and Computation, 32, nr. 3, 2006, p. 641-661.

16.RONALD, L., W., and NICOLE, A., L., The American Statistician, 70, nr 2, 2016, p. 129-133.

17.BHASKAR, B., HABTZGHI, D., The American Statistician, 56, nr. 3, 2002, p. 202-206.

18. REGINA, N., Nature, 506, nr. 7487, 2014, p. 150-152.

19. JAMES, H., M., H., ROBERT, T., O., PETER, B., KARL, K., Biometrics, International Biometric Society, 53, nr. 1, 1997, p. 11-22.

Manuscript received: 2.09 .2018 